\title{
ROBERT B. HALL'S APPROACH TO THE STUDY OF THE JAPANESE BUILT ENVIRONMENT ロバート・B・ホールの日本の建造環境に対する研究アプローチ
}

\author{
Tyana SANTINI* and Takahiro TAJI** \\ サンティニティアナ, 田路 貴 浩
}

\begin{abstract}
During the1920s and 1930s the American geographer Robert Burnett Hall (1896-1975) conducted pioneering research of Japanese cities, towns, and architecture. In Hall's studies, the interpretation of the built environment was based on the culture-nature relationship. But, the understanding of that relationship was being redefined during that period. The $19^{\text {th }}$ century assumption of the deterministic role of nature in the development of societies was changing to the possibilistic viewpoint, according to which nature sets certain constrains but does not determine culture. The following investigation shows how Hall's possibilistic standpoint results in the attribution of significant importance to cultural history in the interpretation of the built environment, while his geographic approach leads to an emphasis on areal distribution and functionality in the formal analysis.
\end{abstract}

Keywords: Robert Burnett Hall, Japanese Built Environment, Geography, Environmental Determinism, Possibilism ロバート・バーネット・ホール, 日本の建造環境, 地理学, 環境決定論, 環境可能論

\section{Introduction}

The prolific career of the American geographer Robert B. Hall (1896-1975) was almost entirely dedicated to the study of Japan. Hall's comprehensive approach to the study of geographic regions has been widely recognized within the field of geography by both American and Japanese scholars. As noted by Akira Watanabe (1904-1984) and Hiroshi Ishida (1919- ), Hall's work played a significant role in the understanding of rural Japan after World War Two (WWII).1) In the late 1940s Hall promoted the study of Japan in the United States and established the Okayama field station where rural life was analyzed by professionals of various disciplines as geography, anthropology, sociology, and even medicine.2)

Although Hall's prominent career after WWII takes most of the attention in discussions about his work, during the 1920s and 1930s he conducted a series of important studies on Japan that have not been as recognized as his later work. The American geographer Norton Ginsburg (1921-2007) has described Hall's regional and systematic geography publications of this period as exemplary and consider them significant for the development of area studies. ${ }^{3)}$ The most extensive discussion of Hall's early studies of Japan is a concise review put together by his biographer John D. Eyre (1922- ), in which he highlighted Hall's unusual interest in the relation between the natural environment and culture. ${ }^{4)}$

As Eyre notes, the limited knowledge of Hall's prewar publications is most likely related to the fact that they could only be found in specialized academic journals and were never published in a book format for a wider audience.

Besides their relevance to the discipline of geography,5) Hall's early publications contain a great amount of valuable and unexamined studies on the Japanese built environment that hold significant importance for the fields of architecture and urban studies. Within the framework of regional studies, Hall analyzed Japanese settlements in the broadest sense of the term, ranging from a single house to a whole city, providing a great amount of new information about Japanese settlements. More importantly, the period in which these studies were made afford two additional reasons that make Hall's publications worthy of consideration.

First, this period saw a significant ideological shift from determinism to possibilism that altered the understanding of the relationship between man and nature. Such understanding affected the interpretation of culture and in consequence, the interpretation
* Doctoral Candidate, Graduate School of Engineering, Kyoto Univ., M. Eng.

** Assoc. Prof., Graduate School of Engineering, Kyoto Univ., Dr. Eng.
京都大学大学院丁学研究科 博土後期課程・修士 (工学) 京都大学大学院工学研究科 准教授・博士 (工学) 
of the material expressions of culture including settlements in all of its forms.

Secondly, Hall was among the first Americans to include the study of settlements, Japanese or otherwise, within the discipline of geography having to sort out how to approach the subject.

This article explores these issues through the examination of Robert B. Hall's works on Japan published before WWII. The main objectives are: (1) to understand Hall's possibilistic interpretation of Japanese built environment and (2) to make clear how Hall studied Japanese cities, villages, and architecture from a geographic approach.

For this purpose, Hall's early career and field trips to Japan are first addressed in Chapter 2. Chapter 3 establishes the ideological context of the field of geography in the first decades of the $20^{\text {th }}$ century in order to make clear the setting in which Hall's studies were carried out. The discussion of Chapter 3 is based on the most influential geography publications of this period, as the works of Ellen Ch. Semple and Carl O. Sauer, also including Hall's works related to the subject to reveal his ideological standpoint. Chapter 4 examines the circumstances in which settlements were included as a study subject in the discipline of geography. Pioneer settlement studies were considered for the discussion including Hall's major references from Unites States and France. Chapter 5 analyzes Hall's studies on Japanese settlements in light of the ideological and disciplinary contextualization addressed in the previous chapters. The analysis of Chapter 5 considers Hall's prewar publications on Japan that include settlement studies. Chapter 6, concludes with a discussion of the stated objectives and topics for further research.

\section{Robert Burnett Hall's early career (1920-1939)}

In 1920, after serving in WWI, Hall entered the University of Michigan obtaining a masters in geography in 1923 and doctoral degree in the same field in 1927. Throughout his academic career Hall continued to be part of the University of Michigan where he entered as an instructor in the department of geography in 1923, becoming a full professor in 1937.6)

Hall's lifelong interest in Japan started after he received a research grant in 1928 to perform field work in the country. Between 1928 and 1937 he made five visits to Japan financially supported by the Social Science Research Council (SSRC) Fellowship, the Social Science Grant-in-Aid for Research in Human Geography in the Japanese Empire, and the Faculty Research Found of the University of Michigan. ${ }^{7)}$

During his trips to Japan Hall worked in association with the Geographical Institute of the Tokyo Imperial University and the Imperial Military Academy. His closest colleague in Japan was Professor Akira Watanabe. ${ }^{8}$ Watanabe was a research fellow at the University of Michigan in 1930 and 1931, and co-wrote with Hall a book entitled Landforms of Japan, focused on the study of natural forms. Although Watanabe's career was dedicated to the study geomorphology, his collaboration in the field trips and translation of official data and Japanese publications significantly enriched Hall's investigation on settlements.

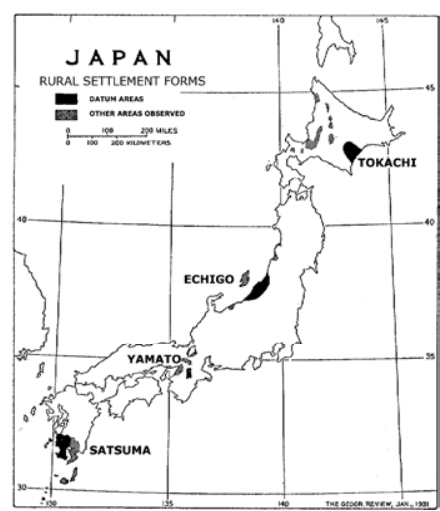

Fig. 1 Areas studied (marked in dark) during the first field trips
During his visits to Japan Hall surveyed areas that were distinctive for their local culture (Fig.1): Satsuma in south Kyushu; Yamato in the Kinki region of southerncentral Honshu; Echigo in north-central Honshu; the province of Izumo; and Tokachi, south-east Hokkaido. The analysis of settlements carried out in these areas was mostly Hinokawa plain in the ancient conducted within the framework of regional geography, which considers all components of the landscape including both natural and cultural elements.

His early studies were the most comprehensive of a small but important wave of Western regional studies on Japan. During the 1920s and 1930s the geographers Ludwig Mecking (1879-1952), 9) Glenn T. Trewartha (1896-1984),10) and Darrell .H Davis (18791962),11) among others, conducted a series of geographic studies that included for the first time the formal analysis of the Japanese built environment. The relevance given to settlements within the study of the regions and the attention given to the interpretation of such settlements varies according to the author. Within these studies, Hall's publications stand out not only for the wider range of settlements considered, but also for the importance assigned to the explanations of settlements, based on the interplay between culture and nature.

\section{The changing understanding of the man-nature relationship}

At the time Hall began his academic studies the discipline of geography in the United States was undergoing an ideological shift. Since mid-19th century American geography was strongly dominated by environmental determinism, initiated after the work of the German geographer Friedrich Ratzel (1844-1904). According to this interpretation of the man-nature relationship, the natural environment had a dominant and unidirectional influence on societies. Human development was understood to be predominantly shaped by geographic and climatic conditions, and therefore the explanations for historical, economical, or cultural traits were searched, and found, within the natural environment. ${ }^{12)}$

In the United States, the most important supporter of environmental determinism was Ratzel disciple Ellen Churchill Semple (1863-1932). Some of her works, as American history and its geographical conditions published in 1903 and Influences of 
Geographic Environment published in 1911, had a great influence on American historians and geographers from the first decades of the $20^{\text {th }}$ century. ${ }^{13)}$ The understanding that the social and economic fate of societies was determined by nature was generally related with social Darwinism, which encouraged the idea that there was a unique and predetermined path of development for societies. The relative position of a society in such path was seen as strongly determined by its geographic and climatic conditions. ${ }^{14)}$

However, during the 1920 s these ideological trends began to change. Regardless of their accuracy, which was being strongly challenged by new researchers, environmental determinism and social Darwinism came to be associated with imperialist and colonialist justifications. As a consequence, most academics avoided any statements that could be linked with these ideologies.

In the United States, the renowned geographer Carl O. Sauer (1889-1975), former professor of Hall's at the University of Michigan, played a major role in the departure from environmental determinism. His most influential article, The Morphology of Landscape from 1925,15) contributed to the redirection of the ideology of American geography towards possibilism. This ideology, initially developed in Europe after the work of Paul Vidal de la Blache (1845-1918), understands nature and culture as interdependent forces. According to the possibilistic approach, man and nature influence each other, and therefore societies and their culture are not perceived as being a product of their natural environment. Moreover, man is seen as the most important agent of geography because just as the wind and rain cause erosion, man modifies the surface of the earth to a great extent. ${ }^{16)}$

This transition of ideologies was neither clear-cut nor limited to these two conflicting concepts. ${ }^{17)}$ The coexistence of different understandings of the relationship between man and nature created several debates on the approach geography should take in the study of the environment. Countless American geographers, including Hall, engaged in the creation of explanatory reports that could provide some guidelines for the study and interpretation of the environment.

In 1924 Hall co-wrote with Preston E. James (1899-1986) two articles on how to proceed in a geographic study: Outline for a Course on the Principles of Geography and A Suggested Outline for the Treatment of a Geographic Region. ${ }^{18)}$ At the time these articles were written the authors were in a conscious transition state “coming out from Semple and joining Sauer". ${ }^{19)}$ Although Semple's influence is still present, as in the conception of geography as the study of the influence of nature on the behavior of living things, $\left.{ }^{20}\right)$ the redirection towards more possibilistic interpretations is also evident. Particularly, the search of causes of human facts in nongeographic factors as culture, for example in the distribution of population, reflects Sauer's approach. ${ }^{21)}$

Eleven years later, in 1935, Hall published another article on geography's approach entitled The Geographic Region: A Resume. ${ }^{22)}$
By this time Hall's statements were far from deterministic implications, even providing explanations against such controversial ideology. In this article Hall explains how different human groups have adapted to the same environments in different ways, also arguing that the same groups in different cultural stages have reacted differently to the same natural conditions. ${ }^{23)}$

Later, in 1938, Hall had the opportunity to apply these ideas in the interpretation of Japan's political and economic situation in an article called Geographic factors in Japanese Expansion. ${ }^{24)}$ Despite the misleading title, Hall stresses the changing role of the natural elements throughout history, presenting as an example the sea. Throughout a review of Japanese history, Hall discussed how the sea represented a threat during some periods, and an advantage during others, depending on the political and technological circumstances of the society. Furthermore, he pointed out that the geography of a country is not a fixed fact referring to the Japanese expansionism, changing therefore not only the relationship of the society with the geography, but the actual geographic conditions. ${ }^{25)}$

The new understanding of the relationship between societies and the natural environment would directly affect the approach to the study of the landscape in the field of geography. Soon more attention was given to the study of the material expressions of man's activities affecting the landscape. However, the appropriate way to study human facts still had to be established.

\section{Cultural Forms, the study settlements in geography}

In the first attempts at the study of human facts the works of the French human geographers Albert Demangeon (1872-1940), Jean Brunhes (1869-1932), and Camille Vallaux (1870-1945) provided the conceptual basis for the analysis. ${ }^{26)}$ As part of geography, the study of human facts was concerned first and foremost with the areal distribution of man's activities and their material representations on the earth surface, or as stated by Demangeon, the territorial link between man and nature. ${ }^{27)}$ These expressions of man's activities included all modifications of the landscape, from land division and agriculture to a single habitation unit. Within these expressions of man's activities there were, according to Brunhes's classification, two essential facts: houses, referring to any kind of constructions, and always in association, the roads. ${ }^{28}$ ) These two elements were the basic components of any human settlement, the most conspicuous expression of man's activities.

The interest in the study of settlements grew within the field of geography in Europe and the United States during the first decades of the $20^{\text {th }}$ century. At the University of Michigan the involvement of Carl O. Sauer, Preston E. James, and Robert B. Hall was essential in redirecting the department of geography to the study of the cultural landscape. ${ }^{29)}$ In the early 1920s Sauer taught the course The Geography of the Settlement of America, while later in the 1930s Hall created a course called Settlements and Preston E. James a course on Urban Geography. ${ }^{30)}$ 
During these first stages of development numerous articles were published discussing possible approaches to the study of the cultural elements of the landscape, or as referred in geography, cultural forms. ${ }^{31}$ In Sauer's influential article from 1925, systematic description was presented as the first step of analysis. ${ }^{32}$ The significance of a purely descriptive survey was questioned, but it was still essential for what could be later analyzed or interpreted in terms of correlations. But even the apparently simple task of descriptive survey represented a problem in the study of cultural facts. There was a lack of adequate terminology for the facts of culture, and no appropriate system in which to place those facts had yet been established. Any classification and organization of data faced problems such as what to include, how to define the facts that were included, and how to determine their relationships.

Another important issue under discussion was the role of history in geographic studies. In this regard the work of Brunhes and Vallaux served again as reference. ${ }^{33)}$ Since the concept of geography now included man's modifications of the landscape, the relationship between history and the natural environment was seen as an interplay. Geography was the setting of history and therefore played an important but not determinant role in history, while at the same time history left its imprint on geography.

Still, this understanding had to come to terms in the practical study of settlements. It was clear that the field of geography was not concerned with the reconstruction of past stages of the cultural forms, but most articles on the subject advised to consider past stages in order to identify relict forms. ${ }^{34)}$ Among the various suggestions made at the time, Hall proposed to layer "occupance upon occupance, as the geologists studied stratification".35) The relict forms could be compared with existing settlements forms and reveal processes of change. To determine such processes, the relict forms had to be interpreted and therefore the knowledge of social and political history becomes essential for the correct interpretation of the material remnants in the analysis of settlements.

It was under this rather new approach with few definite concepts or procedures, that Hall performed the studies of Japanese settlements. As every geographer confronted with the study of human facts, Hall had to rely on a few guidelines that served as basis from which to start the analysis of settlements.

\section{Hall's approach to the study of Japanese settlements}

Between 1926 and 1939 Hall published a total of sixteen articles on Japan, most of them including the study of the built environment. ${ }^{36)}$ The articles dealing with settlements are either regional studies, in which settlements are only a part of the total study of the landscape, or systematic geography studies that address only the specific subject of settlements.

In 1930 Hall published his first article on Japan, The Geography of Manchuria, ${ }^{37)}$ which is in fact a study of a foreign region under
Japanese rule. ${ }^{38)}$ The focus of this regional study is placed on economic activities and their relationship to the natural environment. Urban and rural settlements are here only briefly addressed, but the analysis includes one of the controversial issues of the man-nature debate, that is, the migration of cultures. Japanese cultural forms were set in these foreign territories with a different natural environment from the one in which they were created. Japanese attempts at a rural colonization had failed in this new environment, which may have encouraged a deterministic argument based on the hostility of the natural conditions. Nevertheless, Hall base the explanation of this failure in adaptation not in terms of a negative impact of a difficult environment, but by suggesting a strong influence of the original culture on the settlers. ${ }^{39}$

The first article fully dedicated to the built environment was Some Rural Settlement Forms in Japan published in1931.40) The analysis includes the four regions studied during the first field trips - Yamato, Echigo, Satsuma, and Tokachi (see Fig.1). In each of these areas Hall considers all types of settlements, analyzing them in relation to the natural environment, economic system, and history of the region. Although there is no strict procedure to address each region, the first issue normally considered is the introduction of human facts from another culture as the Han-den system of land division brought from China. These foreign forms were referred as exotic forms, using the word exotic in its original connotation of foreign origin or character. In order to notice these exotic forms, the historical background is explored along with the consideration of the main natural factors. For example, in Satsuma area, Hall explains how the influence of the Shimazu family and the samurai culture are closely related to the social organization, and therefore the land system and settlement distribution of the area, while at the same time the relative political independence is found to be fostered, but not caused, by the isolation provided that the mountain rage. ${ }^{41)}$ The same way, in the examination of Yamato area, Hall states that the drainage conditions favoured the intensive use of the land, ${ }^{42}$ paying more attention in this case to the social structure and political organization imported from China. This way, Hall's explanations of the landscape integrate the natural elements and the most significant cultural or historical events of each region.

In an attempt to trace the origins of the settlements, Hall looks for relict forms in each of the areas studied. In some cases this could be easily done by referring to previous studies, as in Yamato's land division system imported from China for which there were countless publications available. Hall refers to a long list of works in anthropology and economic history of both Western and Japanese authors, as Tokuzo Fukuda (1874-1930) and Matsuyo Takizawa (1898-?),43) to explain the political divisions and land use. But for most of the settlement forms analyzed there were no previous studies that could be used as reference. Consequently, as the analysis of settlements comes close to formal issues like shape 
or organization, Hall's original contribution increases.

Following Brunhes's precepts, which specified that the interest of the geographer was in the most representative type of settlement of a given region, ${ }^{44)}$ Hall establishes one settlement typology for each area. The types recognized in this article, as the Compact Village type of Yamato (Figs. 2 and 3) or the Sastuma house type (Fig. 4) served as reference to Hall in all subsequent articles.

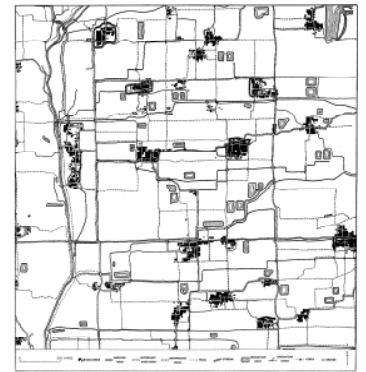

Fig. 2 Yamato, settlement agglomerations (marked agglomeration (marked in black), in black), dispersal study study of village unit

Original scale 1:35.000. Original scale 1:20.000.

In every region, the rural area was examined first to establish the type of distribution of settlements, following with a closer look to the towns or villages found, to finally end with the examination of the habitation unit. In each instance, Hall analyzed the form, meaning the shape in the horizontal plane, and the structure, meaning the functional arrangement and organization of the different parts. These two aspects of the material forms were synthesized in functional schemes while other aspects, as the materials used for the construction or the aesthetic characteristics of the settlements, played a secondary role.

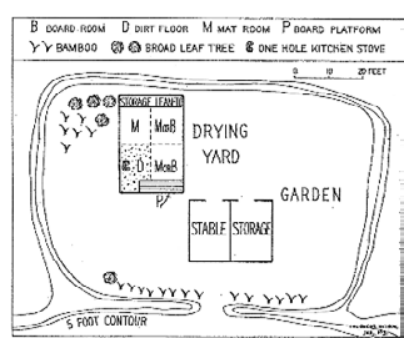

Fig. 4 Satsuma house ground plan. Original graphic scale approximately 1:600
Despite the local differences, Hall perceives an overall homogeneity in Japanese culture and looks for its verification in the material culture.45) This first article on settlements ends with a search for patterns among the cases analyzed. Hall concludes that the form of Japanese rural settlements responds mainly to the natural environment while structure is guided by artificial forces like social or economic events. ${ }^{46)}$ It is precisely in the analysis of structure, or functional arrangement, where Hall's analysis makes constant emphasis, being this topic further developed in subsequent articles.

Following this first article dedicated entirely to the built environment, Hall published three regional studies which address settlements in different degrees: Sado Island in 1932, The Yamato Basin in 1932, and The Hiinokawa Plain in 1933.47) Unlike the previous article, Hall begins these studies with an extensive and thorough survey of the natural environment. This first examination is followed by a series of approaching scales of analysis, concluding again with a close look at the habitation unit (Fig. 4). All regional studies are addressed in a fairly systematic way, but the focus is placed in different issues according to their assumed relative importance in the creation of the cultural landscape. In Yamato, Hall finds the political history to be as important as the agricultural production, while in Hiinokawa plain the floods together with the cultural contact with Korea are considered the main factors affecting the settlement forms.

Throughout these analyses Hall constantly refers to history in order to explain the present state of settlements. In the case of Aikawa, capital of Sado, Hall parallels the stages of the mining industry with the process of the city's growth or decline, revealing the connection between economic history and its material expression. Although the mining industry is strongly related with geographic conditions, Hall stresses in the historical events as changes in technology or fluctuations in the international economic situations affecting the demand. In doing so, Hall establishes once again a relationship between nature and culture that does not imply causation.

Hall's attitude in the interpretation of Japanese cultural facts differs from most of the earlier explanations based mainly on geographic conditions. A good example in this respect is Semple's work Influence of Geographical Conditions Upon Japanese Agriculture from 1912.48) For the analysis of agriculture, Semple considers basically the same elements as Hall including historical, economic, and cultural facts. Nevertheless, in her interpretation, the economic and even the political development are understood to be subordinated to the natural conditions of the country: "Geographical conditions of climate and relief have given a peculiar character to the cultivation and settlement of the country, and hence, to its political development'. ${ }^{49)}$ On the other hand, Hall, as most of his contemporaries, understands that man is the main agent in the creation of the cultural landscape and treats the natural conditions as one of several factors which may or may not be the prevailing cause behind a cultural form.

Besides the new perspective for the interpretation of the Japanese cultural facts, Hall's also had to find tools for their formal analysis. The Yamato Basin is the most significant article in this regard. Because of the lack of defined categories for the study of settlements Hall consciously draws upon terminology and relationship systems from geomorphology stating for instance that "as rivers excave valleys, so road system will be generated by the development of a commercial culture (...)".50)

Regarding graphic analysis, Hall made for this article two complete profiles of the city of Nara covering the entire city. This graphic resource was a standard procedure for natural formations in geomorphology, and in folklore studies was used ti illustrate small sections of rural architecture by some scholars as for example Kon Wajiro (1888-1973).51) Still, Hall's detailed cross-sections of 
Nara city (Fig. 5) were recognized in United States as a valuable contribution for the methodologv of settlement studies. ${ }^{52}$

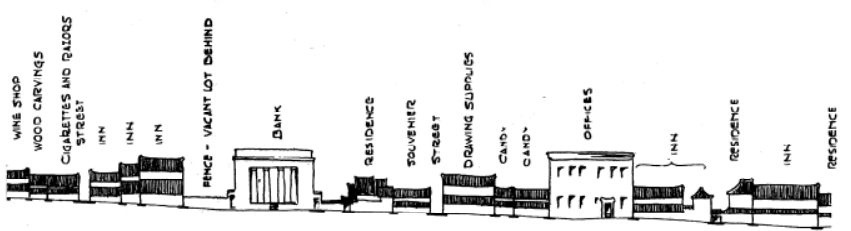

Fig. 5 Portion of the East-West Nara section

In 1934 Hall published two additional papers focused on settlements: Cities, Villages and Houses of Japan, that contains an account of the contents on settlements of the previous papers, and The Cities of Japan: Notes on Distribution and Inherited Forms where Hall deals for the first time with bigger cities like Tokyo and Osaka. ${ }^{53}$

During the 1930s there were no standardized procedures or terminology for the study of cultural forms, let alone for the analysis of cities, the most complex material expression of culture. Still, Hall discusses various aspects of the distribution and patterns of Japanese cities using a combination of German, Japanese and English terms. After establishing a classification of cities by original function, based on a categorization from an economic history of Japan written by Yosaburo Takekoshi (1865-1950), ${ }^{54)}$ Hall discusses in broad terms the functional distribution and layout development of big cities. Also in this case, Hall makes reference to Japanese authors as Odauchi Michitoshi (1875-1954), founder of Japanese human geography. ${ }^{55)}$

Although the treatment of the major urban centers is not exhaustive, the analysis of smaller cities where closer surveys could be performed offers a more detailed formal analysis. Hall presents in this article a number of original functional schemes rarely found in other studies of this period, which illustrate the relationship between morphology and functionality as in the town of Mikkaichi in Toyama Prefecture (shown in Fig.6).

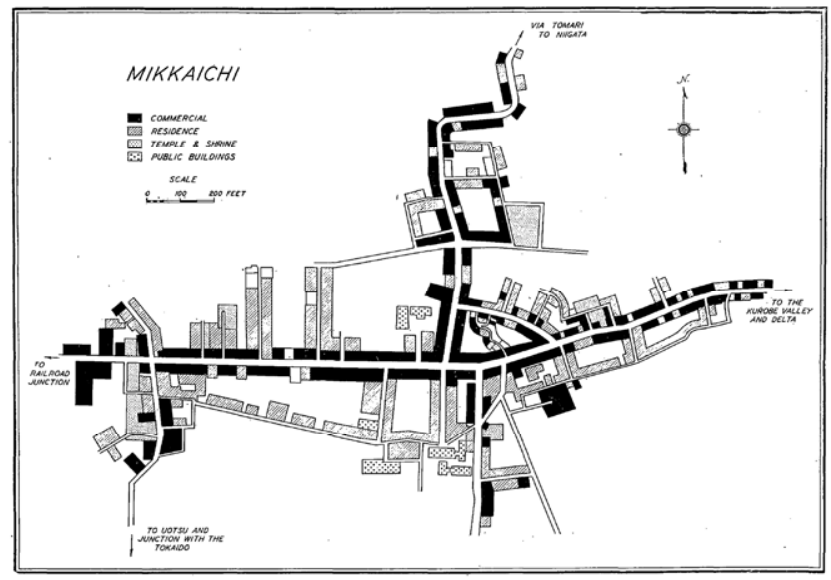

Fig. 6 Mikkaichi functional scheme

The last article published before WW2 that include settlements was Tokaido: Road and Region from 1937.56) To conduct this study,
Hall walked the entire 300 miles of the road together with Watanabe, which gave them a particular insight into the understanding of this road. ${ }^{57)}$ Because of the historical and social relevance of Tokaido, the article contains more historical references than any other. In fact, it could be better characterized as an historical monograph with geographical elements of analysis as opposed to the other way around.

Although this article does not contain much formal analysis of either towns or architecture, the examination of the different relationships of the road with its posts and neighboring villages is extremely valuable. Hall follows the historical development of the area and the expression of this history in the road, analyzing different political periods and the modifications brought by transportation changes. Roads, as facts invariably associated with any human activity, had to be included in the geographic study of settlements, but Hall's interest in roads was mainly directed to the role of roads as integrating forces in the political history of Japan. ${ }^{58)}$

\section{Conclusions}

To address objective (1) Hall's studies were analyzed here on the basis of the new ideological trend. Due to possibilism, natural conditions were no longer taken as the main reasons behind the development of a culture or its material expressions, including settlements. Throughout Hall's studies the precepts of possibilism were always present in the interpretations of Japanese settlements. He establishes correlations between the natural environment and the material expressions of culture, which rarely imply causation. The role of natural forces on the development of settlement forms is never ignored, but because of the discredit that extreme environmental determinism had at the time, Hall is cautious when stating its influence. The departure from determinism allowed Hall to stress the role of the artificial forces in the interpretation of architecture and towns, acknowledging man as the main agent in the creation of the cultural landscape. Moreover, the significance assigned to history replaced the search for causation, characteristic of earlier geographical interpretations, for the tracing of cultural origins.

In order to understand the way in which Hall analyzed Japanese cities, towns, and architecture from a geographic approach, aim of objective (2), the early stage of settlement studies in the field of geography were examined. The first approach to the analysis of settlements was addressed in much the same way as it was done with the natural facts, that is, considering its areal distribution. In his studies of Japanese settlements, Hall begins by considering the distribution of settlements in a geographic region, followed by an approaching scale of analysis that ends with the study of one house. Although this approach was used by other geographers studying Japan, ${ }^{59)}$ Hall's analyses stand out because of the careful study of the intermediate scale, as small towns or sections of cites. Hall's application of the analysis of the areal distribution of man activities 
to smaller areas, as towns or habitation units, resulted in an emphasis on functionality. This emphasis was represented in several functional schemes that provided understanding of the functional interactions between land use, town, and habitation.

Nevertheless, the functions considered were limited to those activities related to the land. As these activities become disassociated from land use, as in the case of urban or religious architecture that respond to highly complex cultural and historical circumstances, the possibilities of analysis from a geographic approach becomes more limited.

Further research on methodology is needed in order to better understand these limitations, as well as to determine the interdisciplinary influences on the development of the formal analysis of settlements.

\section{Notes}

1）石田宽編：外国人による日本地域研究の軌跡, 東京：古今書院, 1985

2) For more on Hall's contributions after WWII see for example: Bedford, Y. $\mathrm{N}$ :アメリカにおけるエアリア・スタディによる日本研究と日本近代化, 人 文地理, 1980, Vol.32 No.6, pp.504-517; 林玉美 : アメリカにおける日本研 究の変遷、日本の「近代化」問題を焦点として, 順正短期大学研究紀要, Vol.34, pp.49-61, 2005; Ward, R. E.: Reflections on the Origins of the Center for Japanese Studies: A Tribute to Robert B. Hall (1896-1975). In Japan in the world, the world in Japan: fifty years of Japanese studies at Michigan, University of Michigan, 2001

3) Ginsburg, N.: Geography and Area Studies, the case of Japan. In Mikesell, M. W. (Ed.): Geographers Abroad, The University of Chicago, 1973

4) Eyre, J. D.: Robert Burnett Hall. In Armstrong P. H. and Martin G. J. (Eds.): Geographers: Bibliographical Studies, Vol. 25, London, Continuum, 2006. p. 83

5) Hall's prewar works are referred in geography publications of the $1960 \mathrm{~s}$, but the contents or circumstances of Hall's studies are not discussed. See for example: Nishi, M.: Regional Variations in Japanese Farmhouses, Annals of the Association of American Geographers, Vol. 57 No.2, pp.239266, Jun. 1967, p.239; and Stone, Kirk H.: The Development of a Focus for the Geography of Settlement, Economic Geography, Vol. 41 No.4, pp. 346-355, Oct. 1965. p.353

6) Ward, Robert E.: Reflections on the Origins of the Center for Japanese Studies: A tribute to Robert Burnett Hall (1896-1975). In, Center for Japanese Studies (Ed.): Japan in the World, the world in Japan: fifty years of Japanese studies at Michigan, University of Michigan, 2001

7) Eyre, J. D., loc. cit.

8) Akira Watanabe (1904-1984) graduated from Tokyo Imperial University in 1925 and was professor in the Imperial Military Academy and Ochanomizu University

9) Mecking, L.: Kult und Landschaft in Japan,in Geographische Anzeiger 30, pp. 137-146, 1929; and Mecking, L.: Japanische Stadtlandschaften, in Passarge, S.: Stadtlandschaften der Erde -Comparative Study of City Landscapes" , Gruyer \& Co, 1931

10) Trewartha, G. T.: Japanese Cities Distribution and Morphology, Geographical Review, Vol. 24 No.3, pp. 404-417, 1934

11) Davis, D. H.: Some Aspects of Urbanization in Japan, Journal of Geography, ,Vol.33 No.6, pp. 205-220, 1934; Type Occupance Patterns in Hokkaido, Annals of the Association of American Geographers, Vol. 24 No.4, pp. 201-223, Dec. 1934; Present Status of Settlement in Hokkaido, Geographical Review, Vol.24 No.3, pp. 386-399, 1934

12) Lewthwaite, G. R.: Environmentalism and Determinism: A Search for Clarification, Annals of the Association of American Geographers, Vol.56 No.1, pp. 1-23, 1966

13) Keighren, I. M.: Bringing Geography to the Book: Charting the Reception of Influences of Geographic Environment, Transactions of the Institute of British Geographers, New Series, Vol.31 No. 4, pp. 525-540, 2006

14) For a detailed discussion on environmental determinism and social Darwinism see Peet. R.: The Social Origins of Environmental Determinism, Annals of the Association of American Geographers, Vol. 75 No.3, pp. 309-333, 1985

15) The Morphology of Landscape was initially published in University of California Publications in Geography, Vol.2 No.2, 1925 (Reprinted 1938).

16) Brunhes, J.: Human Geography. An attempt at a Positive Classification, Principles and Examples, trans. by LeCompte, I. C., Rand McNally \& Co., NY, 1920, p.42

17) For an extensive consideration of this subject see for example Campbell J. A. and Livingstone, D. N.: Neo-Lamarckism and the Development of Geography in the United States and Great Britain, Transactions of the Institute of British Geographers, New Series, Vol. 8 No. 3, pp. 267-294, 1983 and Lewthwaite R. G. loc.cit.

18) James, P. E. \& Hall, R. B.: Outline for a course on the principles of geography, Ann Arbor, Mich. Edwards Bros., 1924; A Suggested Outline for the Treatment of a Geographic Region, Journal of Geography, Vol.23 No.7, pp. 288-291, 1924

19) James P. E. words from a letter quoted in Martin Geoffrey J.: In Memoriam: Preston E. James, 1899-1986, Annals of the Association of American Geographers, Vol. No.1, pp.164-175, 1988

20) James, P. E. \& Hall, R. B.: Outline for a course on the principles of geography, loc. cit., p.1

21) James, P. E. \& Hall, R. B.: A Suggested Outline for the Treatment of a Geographic Region, loc.cit., p.290

22) Hall, R. B.: The Geographic Region:A Resume, Annals of the Association of American Geographers, Vol.25 No.3, 1935

23) Ibid., p. 125

24) Hall, R. B.: Geographic Factors in Japanese Expansion, Proceedings of the Institute of World Affairs, 16th session, pp.46-55, 1938, The University of Southern California, 1939. This article was part of an analysis of the political situation of that period, which included the analysis of geographic, economic, and social factors in World Affairs

25) Ibid., p.53

26) See for example Demangeon, A.: La Géographie de l'Habitat Rural, Annales de Géographie, Vol. 36 No.199, pp. 1-23, 1927; Brunhes, J.: Human Geography, trans. by LeCompte, I. C., Rand McNally \& Co., NY, 1920; Vallaux, C.: Les Sciences Géographiques, Félix Alcan, 1925

27) Demangeon, A.: Problèmes de la Géographie Humaine, Librairie Armand Colin, Paris, fourth edition, 1952. p.31

28) Brunhes, J.: Human Geography, loc. cit, p.48

29) The term Cultural Landscape - Kulturlandschaft was first introduced by the German geographer Otto Schluter (1872-1959), in 1906 in Objectives of Geography of Man -Die Ziele der Geographie des Menschen-, R. Oldenbourg, 1906

30) Shaw W. B. (Ed.): The University of Michigan, an encyclopedic survey, Vol. 2, parts III, IV and V, Ann Arbor, University of Michigan Press, 1951. P. 582

31) Some good examples are; James, P.E.: The terminology of regional description, Annals of the Association of American Geographers, Vol.24 No.2, pp. 78-92, 1934 and, in the same issue, Johns W. D.: Procedures in Investigating Human Occupance of a Region, Annals of the Association of American Geographers, Vol.24 No.2, pp. 93-111, 1934

32) Sauer, C. O., 1925, loc. cit., p.327

33) Particularly Vallaux, C. and Brunhes, J.: La géographie de l'histoire: géographie de la paix et de la guerre sur terre et sur mer, Félix Alcan, 1921. The thorough review in English by Douglas W. Johnson, in Geographical Review in 1922, was an important reference for American Geographers

34) See for example: Whittlesey, D.: Sequent Occupance, Annals of the Association of American Geographers, Vol.19 No.3, pp. 162-16, 1929; and Dodge R. E., The Interpretation of Sequent Occupance, Annals of the Association of American Geographers, Vol.28 No.4, pp 233-237,1938

35) From the records of Robert B. Hall presentation of the Great Lakes 
studies, in Round Table on problems in Cultural Geography, Annals of the Association of American Geographers, Vol.27 No.3, pp. 155-175, 1937. p.168

36) The articles that do not include the study of settlements are: Landforms of Japan, 1932; Agricultural regions of Asia: Part VII, The Japanese Empire, Annals of the Association of American Geographers, Pt. 1, Vol.10 No.4, 1934; Pt. 2 Vol.11 No.1, 1935; Pt.3 Vol.11 No.2, 1935; Geographic Factors in the Japanese Empire, loc. cit., 1937; The Expansion of the Japanese Empire, Fifth annual Adult Education Institute, 1937

37) Hall, R. B.: The Geography of Manchuria, Annals of the American Academy of Political and Social Science, Vol. 152, pp. 278-292, Nov. 1930

38) The researched area of Kwantung (Liaodong Peninsula) was under Japanese power officially from 1905 to 1945

39) Hall, R. B.: The Geography of Manchuria, loc. cit., p.290

40) Hall, R. B.: Some Rural Settlements Forms in Japan, Geographical Review, Vol.21 No.1, pp. 93-123, 1931

41) Ibid., p.102

42) Ibid., p.94

43) Fukuda, T.: The Social and Economic Development of Japan -Die gesellschaftliche und wirtschaftliche Entwickelung in Japan-, Stutgart, 1900; Takizawa, M.: The penetration of money economy in Japan and its effects upon social and political institutions, Columbia University press 1929

44) Brunhes, J: Human Geography, loc. cit., p.75

45) Hall, R. B.: Some Rural Settlements Forms in Japan, loc cit., p.93

46) Ibid., p. 122

47) Hall, R. B.: Sado Island, Michigan Academy of science Arts and Letters, Vol. 16, Ann Arbor, pp. 275-297,1932; The Yamato Basin, Japan, Annals of the Association of American Geographers, Vol.22 No.4,pp. 243-292, 1932; The Hiinokawa Plain, Papers Fifth Pan-Pacific Science Congress, pp.1395-1371, 1933

48) Semple, E. Ch., 1912, Influence of Geographical Conditions Upon Japanese Agriculture, The Geographical Journal, Vol.40 No.6, pp.589603,1912

49) Ibid., p. 591

50) Hall, R. B.: The Yamato Basin, Japan, loc. cit., p. 280

51) See for example 今和次郎: 日本の民家, 増訂版, 岡書院, 1927, p.99 and 167

52) Fead, M. I.: Notes on the Development of the Cartographic Representation of Cities, Geographical Review, Vol.23 No.3, pp. 441-456, Jul. 1933. p.455

53) Hall, R. B.: Cities, Villages and Houses of Japan, The Quarterly Review of the Michigan Alumnus, pp. 138-149, 1934; The Cities of Japan: Notes on Distribution and Inherited Forms, Annals of the Association of American Geographers, Vol.24 No.4, pp. 175-200, 1934

54) Takekoshi, Y.: The economic aspects of the history of the civilization of Japan, George Allen \& Unwin, 1930

55) Besides Odauchi Michitoshi, the authors more frequently refereed in Hall's studies are Nishida Yoshiro (1884-1952), Ogawa Takuji (18701941), and Watanuki Isahiko (1892-1943)

56) Hall, R. B.: Tokaido: Road and Region, Geographical Review, Vol.27 No.3, pp. 175-200, 1937

57) Eyre, J. D., loc.cit, p.87

58) In 1942 Hall published another work on the subject - The Road in Old Japan, Studies in the History of Culture, The American Council of Learned Societies, 122-55 - where he analyzed the relation between the political history and the communication system

59) See the articled of Glenn Trewartha and Darril Haugh Davis mentioned in Note 3, which consider mainly distribution of settlements and the habitation unit without including intermediate scales of study

\section{Image sources}

Fig. 1. Hall, R. B: Some Rural Settlements Forms in Japan, Geographical Review, Vol.21 No.1, pp. 93-123, 1931, p.93

Fig. 2. Ibid. p.97

Fig. 3. Ibid., p.107

Fig. 4. Ibid., p.104
Fig. 5. Hall, R. B:The Yamato Basin, Japan, Annals of the Association of American Geographers, Vol.22 No.4,pp. 243-292, Dec. 1932, (n.p., attachment)

Fig. 6. Hall, R. B: The Cities of Japan: Notes on Distribution and Inherited Forms, Annals of the Association of American Geographers, Vol.24 No.4, pp. 175-200, 1934, p.197 


\section{和文要約}

まえがき

1920 年代から 1930 年代にかけて、アメリカ人地理学者ロバート・ バーネット・ホール（Robert Burnett Ha11，1896-1975）は、日本の 都市、集落、建築にかんして調查研究を実施し論考を発表したが、そ れはこの分野で当時もっとも包括的な研究であった。ホールの調查研 究には二つの重要な背景がある。第一には、当時、地理学において重 大な理論的変化が進行していたことである。19 世紀における自然に よる環境決定論的な理解は、文化と自然が相互に影響を及ぼしあう環 境可能論的な理解へと転換しつつあった。第二に、ホールは地域研究 にかんする第一世代の地理学者であったため、調查対象に接近するた めの方法論を新たに考案する必要があった。

本稿は、第二次大戦以前に公表されたロバート・B・ホールの日本 にかんする論考を対象に、次の二つを試みる。1）ホールの日本の建 造環境にかんする環境可能論的立場からの解釈を理解する。2) ホール は地理学的アプローチから、どのように日本の都市、集落、建築を調 查研究したかを明らかにする。

\section{理論的変化}

ホールが研究調査をはじめた 1920 年代、アメリカでは地理学の理 論的基盤が変わりつつあった。19 世紀の中頃から、アメリカの地理学 では環境決定論が優勢であった。この理論によれば人類の発展は主に 地理的・気候的情況によって形成される。しかし、1920 年代になる と、この理論は自然と文化を相互に影響しあう「独立した力」とみな 寸環境可能論へと移り変わっていった。

ホールの初期の論考には、環境決定論的理論と環境可能論的理論の 双方の要素が含まれている。とはいえ、ホールが日本研究を始めるに 至るころには、彼の立場は環境決定論的ではなく、むしろこれに対峙 するものとなっていた。たとえば、同じ集団が様々な文化的段階にお いて、自然状況に対してどのように異なる反応を示したかということ が説明されている。

\section{文化的形態と地理学における集落調査}

人間と自然に関する新しい理解は、集落を含む文化的要素の研究に 重要性を与えたが、その研究にふさわしい方法についてはいまだ議論 の直中にあった。単純に見える記述的調查にも課題があった。という のも、記述のための専門用語や分類方法が欠如していたのである。建 造環境の分析の基礎となる手引きはわずかしかなかった。人間活動の 地域的分布は地表面の物質的特性と関連づけて説明されていたが、こ れらの物質的説明の解釈の正しさのために、社会史、政治史の知識が 必要不可欠であると考えられていた。

\section{日本の集落にかんするホールの論考}

1925 年から 1939 年の間、ホールは日本の集落にかんする 9 編の論 考を発表している。そのうち 4 編は特定の対象地域をとり上げてい る。上述のように、調查のための固有の方法論がなかったため、集落 の分析は新しいアプローチによって行われた。

1931 年、「日本の田園の集落形態」が発表された。これは、ホール がはじめて集落をとり上げた論考である。4つの地域が選ばれ、それ ぞれの地域における住居を含む集落類型が提示された。また、自然環 境の記述にあたっては、文化的特徴を促進する具体的な情況が強調さ れている。ホールの関心はそれぞれの地域の文化的・歴史的背景にも 向けられており、なかでも「外来形態」の導入がとり上げられている。
彼のもつとも独創的な貢献は、地形、機能的配置、様々な構成要素か らなる組織にかんする構造の形式的分析であった。ホールは村落の形 態が主に自然環境に応答しているのにたいし、構造は社会や経済の実 体としての「人為的力」によって導かれようとしていることを発見し た。このように構造分析は人為的力と関連づけられており、この点に おいて彼の集落研究は際立っていた。

1932 年の「日本の大和盆地」は、第二次世界大戦以前に発表された 論考の中で、もっとも広範囲にわたる地域研究である。自然地域の調 查にはじまり、住居の細部にいたるまで、いくつかの異なる尺度にお いて行われている。また、集落研究にかんする定まった方法が欠如し ていたために、関係する体系、方法論、専門用語は地形学から借りら れている。しかしながら、詳細に作成された奈良市の断面図は独自の 方法論として評価されている。

1934 年の「日本の都市」は、当時の日本の都市にかんする欧米人の 研究のなかで、もっとも完成度が高いものであった。この論考が書か れたとき、都市分析の方法論は初期の発展段階であった。ホールは東 京や大阪など大都市における機能的な分布とその発展形態について 議論している。しかし、彼の形式分析は小規模な都市においてより完 成度が高く、建造環境の詳細を幅広く記述している。都市分類のため の標準的な記述用語が久如していたため、日本語、ドイツ語、英語の 用語が混合して使用されている。そのようにしながら、ホールは固有 の機能にしたがって日本の都市類型を措定した。

結

1）ホールの日本の建造環境についての解釈には、環境可能論の指 針がつねに含まれていた。彼は、因果関係とは異なる自然環境と建造 環境の相互関係を読み取ろうとしていた。当時、極度な環境決定論に よって引き起こされたその信用の失墜のために、ホールは建築や都市 が建造された場所における自然の影響から出発しょうとしてはいる が、彼はその点についてきわめて慎重であった。くわえて、建造環境 の解釈において歴史に重要性を与え、文化的起源の調査を推し進めた 2）地理学的アプローチは、最初、ある特定の地域における諸要素 の地域的分布を規定し、次いで、この分布の原因の分析とこれらの諸 要素間の関係へと進展した。ホールはこのアプローチを建造環境の研 究に応用し、その結果、地域や都市、集落、建築を問わず、水平的 な分布の機能的分析が強調された。多くの地理学者が同様のアプロー チをとったが、ホールにおいては、小集落や都市の断面図に見られる ように、その中間的尺度の研究が際だっている。

ホールが捉えていた機能は土地に関連づけられた活動に限定され ていた。しかし、これらの活動はしだいに土地と連帯しなくなり、高 度な文化的・歴史的環境の複合体に応答寸る都市や地方の建築の事例 においては、地理学的アプローチからの可能性の分析はより制約され るようになっていった。

（2013年10月10日原稿受理，2014年 5 月 8 日採用決定） 